\title{
A Vibrant Soundbridge aktív középfül-implantátum történeti áttekintése és sebészi alkalmazásának lehetőségei
}

\author{
Tóth Tamás - Gerlinger Imre dr. - Bölcsföldi T. Barbara dr. \\ Kellényi György - Németh Adrienne dr. \\ Papp István dr. - Szanyi István dr.
}

Pécsi Tudományegyetem, Általános Orvostudományi Kar, Fül-Orr-Gégészeti és Fej-Nyaksebészeti Klinika, Pécs

\begin{abstract}
A Vibrant Soundbridge aktív középfül-implantátum vezetéses, sensorineuralis és kevert típusú halláscsökkenés esetén is megoldást jelenthet a beteg hallásrehabilitációja során. Sensorineuralis halláscsökkenés esetén akkor indikálható, ha a légvezetéses hallásküszöb nem haladja meg a 80-85 dBHL-t a 3-4 kHz frekvenciákon, vezetéses, illetve kevert típusú halláscsökkenés esetén pedig akkor, ha a csontvezetéses hallásküszöb nem haladja meg a 45-65 dBHL-t a 0,5-4 kHz közti frekvenciatartományban. Az implantátum beültetését eleinte tisztán sensorineuralis halláscsökkenés esetén végezték, és csupán egyféleképpen történhetett: a rezgéskeltő rendszer oldalán lévő rögzítőcsipeszt rá kellett applikálni az incus hosszú nyújtványára. Azokra az esetekre, amikor a rezgéskeltő rögzítése nem kivitelezhető, különböző rögzítőelemeket (coupler) fejlesztettek ki. Az incusra való rögzítés hosszúnyújtvány-couplerrel, illetve rövidnyújtvány-couplerrel lehetséges. Vezetéses és kevert típusú halláscsökkenés esetén a kerek ablak membránjához is illeszthető a rendszer, előrehaladott otosclerosis esetén pedig a Soundbridge-implantáció stapedotomiával kiegészített változata („power stapes”) hozhat kielégítő halláseredményt. Ezek a technikák meglehetősen megnövelték a sebész szabadságát, így széles körben alkalmazott, megbízható megoldássá váltak. A Pécsi Tudományegyetem Fül-OrrGégészeti és Fej-Nyaksebészeti Klinikáján az elmúlt évtizedben számos incusvibroplastica történt, de kerekablakvibroplasticára is több alkalommal sor került. A jelen összefoglaló tanulmányban a Vibrant Soundbridge implantátum technikai fejlődésének történeti áttekintésén felül az alkalmazható mútéti megoldásokat mutatjuk be.
\end{abstract}

Orv Hetil. 2021; 162(40): 1619-1626.

Kulcsszavak: coupler, középfül-implantátum, műtéti technika, Vibrant Soundbridge

\section{Historical overview and surgical applications of the Vibrant Soundbridge active middle ear implant}

The Vibrant Soundbridge active middle ear implant can provide a reliable solution for hearing rehabilitation of patients with conductive, sensorineural or mixed hearing loss. For sensorineural hearing loss, the air conduction threshold of the patient should not be more increased than $80-85 \mathrm{dBHL}$ at the range of $3-4 \mathrm{kHz}$, and for conductive and mixed hearing loss, the bone conduction threshold should not be more increased than 45-65 dBHL between 0.5 and $4 \mathrm{kHz}$. The standard surgical procedure was originally designed for purely sensorineural hearing loss, and the fixation clip of the vibrating transducer needed to be crimped onto the long process of the incus. In many cases, it is impossible to crimp the vibrator onto the incus. In order to solve such circumstances, fixation clips (couplers) have been developed. There are two options to crimp the device on the incus: applying a long process coupler or a short process coupler. For conductive or mixed hearing loss, a round window soft coupler has been introduced. In advanced otosclerotic cases, a special combined technique of Soundbridge implantation with simultaneous stapedotomy can result in sufficient hearing rehabilitation. These techniques significantly broadened the scale of possibilities for the implantation, therefore, it became a widely utilized, reliable procedure. At the Department of Otorhinolaryngology, Clinical Center, University of Pécs, in addition to a noteworthy amount of incus vibroplasty, several cases of round window vibroplasty have also been performed. The aim of the present study is to summarize the history of development of the Vibrant Soundbridge and to present an overview of the applicable surgical techniques. 
Keywords: coupler, middle ear implant, surgical technique, Vibrant Soundbridge

Tóth T, Gerlinger I, Bölcsföldi TB, Kellényi Gy, Németh A, Papp I, Szanyi I. [Historical overview and surgical applications of the Vibrant Soundbridge active middle ear implant.] Orv Hetil. 2021; 162(40): 1619-1626.

(Beérkezett: 2021. február 14.; elfogadva: 2021. március 29.)

\begin{abstract}
Rövidítések
$\mathrm{dBHL}=($ decibels hearing level $)$ decibel hallásszint; FDA $=$ (U.S. Food and Drug Administration) az Amerikai Egyesült Államok Élelmiszer-biztonsági és Gyógyszerészeti Hivatala; FMT = (floating mass transducer) rezgéskeltô rendszer; LP-C $=($ long process coupler $)$ hosszúnyújtvány-coupler; MRI = (magnetic resonance imaging) mágnesesrezonancia-képalkotás; NEAK = Nemzeti Egészségbiztosítási Alapkezelő (az OEP jogutódja); PTA $=$ (pure tone audiometry) tisztahang-audiometria; PTE KK = Pécsi Tudományegyetem, Klinikai Központ; $\mathrm{RW}-\mathrm{SC}=$ (round window soft coupler) kerek ablak lágy coupler; $\mathrm{SP}-\mathrm{C}=$ (short process coupler) rövidnyújtvány-coupler; SRT $=$ (speech reception threshold) beszédhallásküszöb; TICA $=($ totally implantable cochlea amplifier $)$ teljesen implantálható cochleaerősítő; USA = (United States of America) Amerikai Egyesült Államok; VORP = (vibrating ossicular replacement prosthesis) vibráló csontpótló protézis; VSB = Vibrant Soundbridge; WRS = (word recognition score $)$ százalékos beszédértés
\end{abstract}

A különböző etiológiájú vezetéses, valamint kevert típusú halláscsökkenésben szenvedő betegek hallásrehabilitációjára is egészen az 1990-es évekig - az adenotomián és a ventilációstubus-behelyezésen kívül - csupán a tympanoplastica és a stapedotomia jelenthetett mútéti megoldást. A sensorineuralis halláscsökkenésben szenvedő, hagyományos hallókészülékekkel ellátott betegek esetében pedig - akár fül mögötti, akár hallójárati készülékrő́l volt szó - a viselés és a hallásélmény terén is előfordulhattak nemkívánatos tényezők. A torzítás, az okklúziós effektus és az akusztikus gerjedés problémái minimálisra csökkenthetők nyitott illesztés, illetve illesztékfuratok alkalmazásával, viszont komoly kellemetlenséget jelenthet, ha a beteg hallójárati ekcémától szenved, vagy allergiás reakciót vált ki az illeszték. Továbbá fokozott cerumentermelés vagy rekurráló otitis externa nehezítheti meg a készülék viselését. Vannak olyan esetek is, amikor fel sem merülhet a hagyományos légvezetéses hallókészülék viselete, mivel a fülkagyló vagy a hallójárat anatómiai rendellenessége, esetleg a hallójárat teljes atresiája/stenosisa megakadályozza azt.

Az ilyen problémák esetén jelenthet megoldást az aktív középfül-implantátumok használata. Ez az implantátumrendszerek olyan csoportja, melynél a rezgéskeltó egység a középfüil valamelyik képletére, struktúrájára rögzítendő. Közülük manapság a legrégebbi és legelterjedtebb eszköz a Vibrant Soundbridge (VSB), mely már több mint 20 éves múltjával és megbízhatóságával köz- kedvelt hallásjavító megoldássá vált a fülsebészek kezében.

Hazánkban 2014-ben került először finanszírozásra (korlátozott számban), és azóta is elérhető. Napjainkig a pécsi Fül-Orr-Gégészeti és Fej-Nyaksebészeti Klinikán 24 beteg hallásrehabilitációja történt meg VSB-implantáció segítségével.

Közleményünk célja, hogy bemutassuk az aktív középfül-implantátumok fejlődésének mérföldköveit, majd részletesen ismertessük a VSB felépítését, múködési mechanizmusát, alkalmazható mútéti technikáit és indikációs körét, valamint a hazai és a nemzetközi tapasztalat tükrében szemléltessük a hallásrehabilitációban elért hatékonyságát.

\section{A középfül-implantátumok fejlődésének történeti áttekintése}

Az 1930-as évek elején Wilska kísérleteivel indult meg egy szemléletbeli váltás, egy új irányvonal az eszközös hallásjavítás terén. Wilska a dobhártyára vasrészecskéket helyezett, melyek a hallójáratba illesztett elektromágneses tekercs harmonikusan változó mágnesterének hatására egy adott frekvenciájú rezgő mozgásba kezdtek, megrezgetve ezzel a dobhártyát. Az így kapott mechanikus rezgés hallásélményt váltott ki a páciensben $[1,2]$.

Hough és munkacsoportja már a dobüregen belülre tervezte az implantátum rezgő részét. Ők vas helyett egy parányi mágnest rögzítettek az incudostapedialis ízületre, hogy az energiaátadásban nagyobb hatásfokot érjenek el. Az új ötlet „SOUNDTEC” néven vált ismertté [3]. Később megjelent ennek továbbfejlesztett változata, a MAXUM rendszer (Ototronix, Houston, TC, USA), melynek külső egységét már akkorára miniatürizálták, hogy teljes egészében a hallójáratban foglalhatott helyet [4-6].

Az „Earlens”-ként ismert találmányában Perkins egy viszkózus ásványolaj segítségével a dobhártyára tapasztott fel mágnest. Ezt elektromágneses nyaklánc hajtotta meg, azonban ez a konstrukció nagyon rossz hatásfokkal rendelkezett. A fejfordítás okán koaxialitási problémák is felléptek, így az eszköz bizonyos fejhelyzetekben egyszerúen hatástalan volt [7].

Az 1990-es évek végén Tübingenben, Németországban fejlesztette ki Zenner a TICA (totally implantable cochlea amplifier - teljesen implantálható cochleaerósítő) nevü készülékét, melynek belső egysége a dobüreg- 


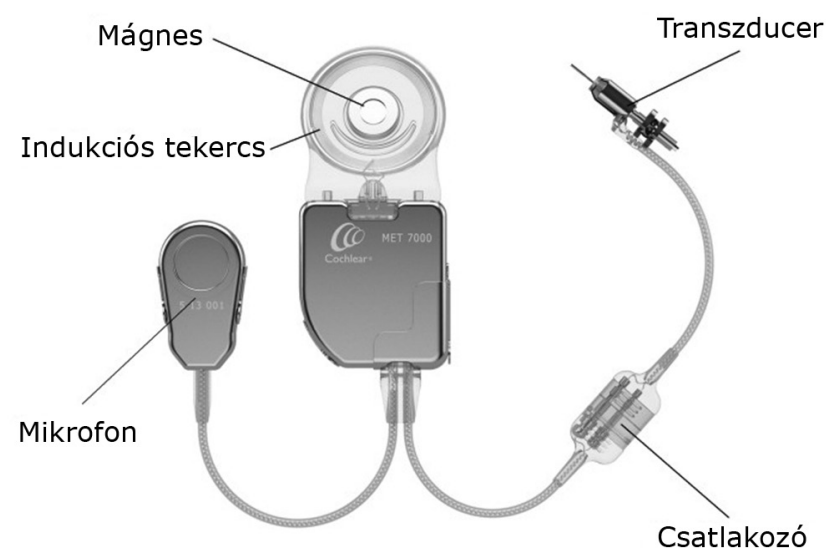

1. ábra

A Carina középfülimplantátum-rendszer (Otologics LLC, Boulder, CO, USA)

ben foglalt helyet, és a stapes talpát hozta rezgésbe. Több tucat beteg esett át ilyen implantáción, de a hanghullámok visszacsatolódása okán gyakran fellépő zúgás, sípolás, gerjedés (ún. akusztikus feedbackjelenség) miatt az új eszköz nem terjedt el a klinikai gyakorlatban $[8,9]$.

A kezdeti kísérletek óta csupán néhány olyan eszköz jelent meg, mely a mai értelemben vett „középfül-implantátum” kategóriába sorolható. Ilyen a Carina, az Esteem, a Codacs és a VSB.

A Carina (Otologics LLC, Boulder, CO, USA) teljes egészében beültethető középfül-implantátum, mely nemcsak a rezgés létrehozásáért felelős egységet, hanem a mikrofont és az újratölthető akkumulátort is magában foglalja (1. ábra), tehát az indukciós elven múködő akkumulátortöltőn kívül nincs szükség külső eszköz használatára, így nem jelent társadalmi stigmát a beteg számára. Hátránya azonban, hogy mivel a mikrofon is be van ültetve a bőr alá, gyakran a testzajokat (rágás, nyelés, erek pulzálása) is felerősíti a készülék $[10,11]$.

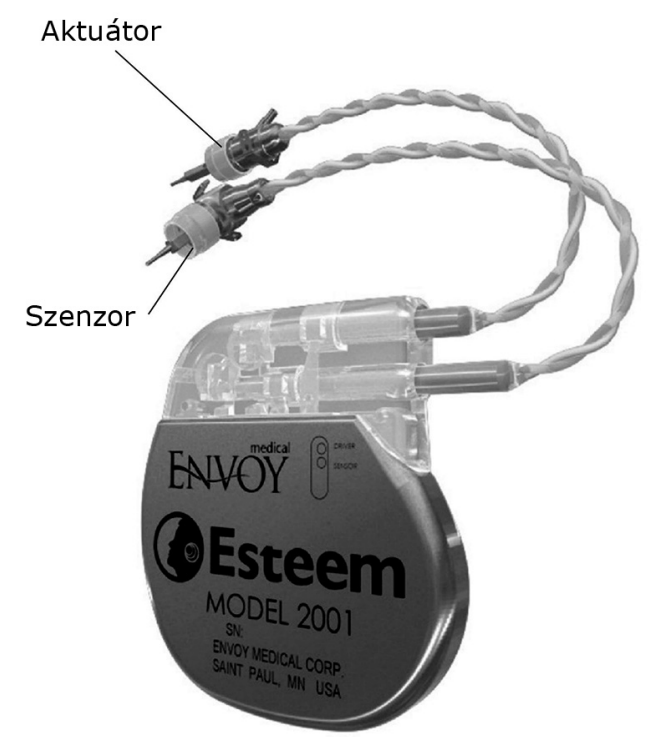

2. ábra

Az Esteem középfülimplantátum-rendszer (Envoy Medical Corporation, St. Paul, MN, USA)

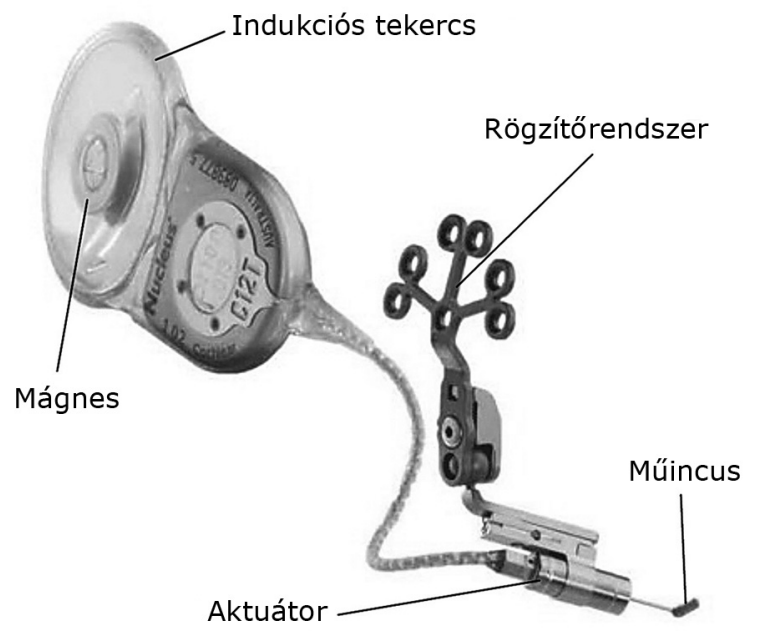

3. ábra

A Codacs középfülimplantátum-rendszer beültethető egysége (Cochlear Ltd., Melbourne, Ausztrália)

Az Esteem (Envoy Medical Corporation, St. Paul, MN, USA) implantátum ettól annyiban tér el, hogy mikrofon helyett egy olyan szenzor veszi fel a rezgést, mely direkt kontaktusban áll az incusszal, majd a felerősített jelet egy aktuátoron keresztül az incustól elkülönített stapesfejhez továbbítja (2. ábra). Ez a konstrukció már jóval kevésbé érzékeny a nemkívánatos testzajokra [12].

A Codacs (Cochlear Ltd., Melbourne, Ausztrália) direkt akusztikus cochleastimulátor két egységből áll. Az implantátum csak a rezgést keltő aktuátort tartalmazza, mely speciális rögzítőrendszerrel pozicionálható, és egy múincusra applikált pistonnal kapcsolódik a stapes talpán kialakított stapedotomiás nyíláshoz, így a rezgés közvetlenül a perilymphatérre tevődik át (3. ábra). Az egész rendszert meghajtó beszédprocesszor a mikrofonnal és az áramforrással együtt egy külső egységben kapott helyet [13].

A VSB (MED-EL, Innsbruck, Ausztria) aktív középfül-implantátumos rendszer ugyancsak két különálló egységből tevődik össze. Az audioprocesszor feldolgozza és modulálja az érzékelt akusztikus jelet, majd egy indukciós tekercspár segítségével demodulátoron keresztül továbbítja a középfül valamelyik képletéhez rögzített rezgéskeltő rendszernek. A részben beültethető középfül-implantátum először 1994-ben került forgalomba (Symphonix Devices Inc., San Jose, CA, USA), majd az Egyesült Államokban egy 53 beteg bevonásával végzett, komplex hallásrehabilitációs és biztonsági vizsgálatokat magában foglaló kutatás után 2000-ben az FDA (Food and Drug Administration) által engedélyezett első középfülimplantátum-rendszerré vált [14].

Az osztrák cég egy amerikai elektromérnök, Geoffrey Ball (a készülék feltalálója) újabb fejlesztéseinek bevezetésével kifinomult és széles körben alkalmazható, közkedvelt hallásjavító implantációs megoldássá tette a piacképes találmányt. Erről és az ebben az időszakban megjelent további középfül-implantátumok fejlődéséről Carlson részletesen beszámolt [15]. 
Meggyőző audiológiai eredményei és nagyfokú elterjedtsége, közkedveltsége miatt ebben a tanulmányban a továbbiakban kizárólag a VSB áttekintésére fókuszálunk. Bemutatjuk funkcionális felépítését, majd betekintést nyújtunk a mútéti megoldások széles palettájába, és öszszegezzük a különböző betegségcsoportok esetén figyelembe veendő indikációs kritériumokat, megfontolásokat. Ezután néhány nemzetközi statisztika és saját tapasztalat megosztásával demonstráljuk az eszköz hatékonyságát, előnyeit és hátrányait.

\section{A Vibrant Soundbridge felépítése és müködése}

A VSB külső készüléke (audioprocesszora) jelenleg a Samba ${ }^{\mathrm{TM}}$, mely adaptív iránymikrofonokkal ellátott, digitális hangfeldolgozó egység. Tartalmazza az elemtartót és a beültetett egységgel való kommunikációhoz szükséges indukciós tekercset egy (a bőrlebeny vastagságától függő erősségû) cserélhető rögzítőmágnessel (4. ábra). $\mathrm{Az}$ audioprocesszor feldolgozza és szüri a mikrofonok által rögzített hangszignált, majd modulált elektromos jellé alakítva az indukciós tekercs segítségével a bőrlebenyen keresztül továbbítja a beültetett egységnek.

Az implantátum (VORP - vibrating ossicular replacement prosthesis, 5. ábra) vevőtekercse fogadja az információt, továbbítja a demodulátornak, mely összekötő vezetékkel csatlakozik a rezgéskeltő rendszerhez (FMT - floating mass transducer). Az FMT a középfül több képletéhez is rögzíthető (incus, stapes, kerek ablak). Végeredményként a mechanikai vibráció áttevődik a perilymphatérre, majd ettől kezdve az adott hang érzékelése és központi idegrendszeri feldolgozása a szokott funkcionális anatómiai módon zajlik.

Az FMT egyszerúsége abból adódik, hogy az előző konstrukciós ötletekkel szemben (ld. SOUNDTEC, Earlens, TICA) a komplett „rezgőmotor” - a mágnes és a tekercs - egyetlen aranybevonatú titániumhengerben foglal helyet, melyben a mágnes tehetetlen tömegként vibrál a meghajtó feszültségjel frekvenciájának és amplitúdójának függvényében. Az elmozdulások nagyság-

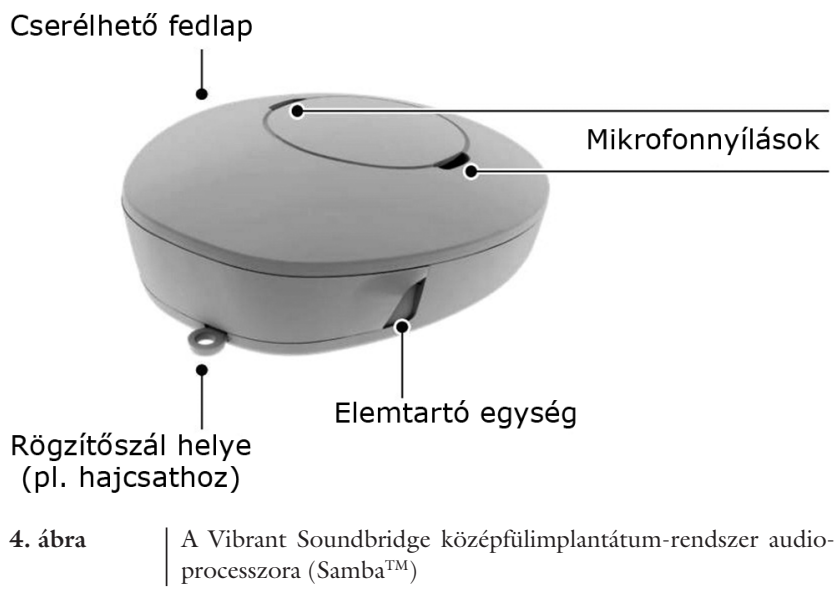

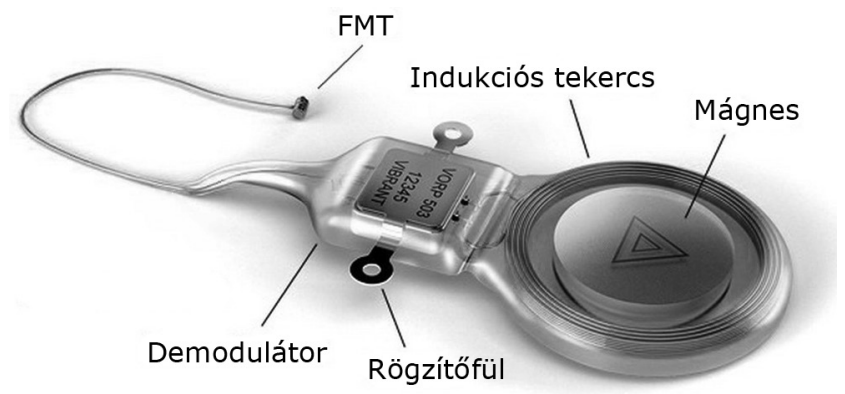

5. ábra

A Vibrant Soundbridge középfülimplantátum-rendszer beültet hető egységének (VORP 503) felépítése

FMT = rezgéskeltő rendszer

rendje 0,001-0,1 mikron (egy átlagos hajszál vastagsága 60-80 mikron), az eszköz által lefedett frekvenciatartomány pedig $100 \mathrm{~Hz}$-től $10 \mathrm{kHz}$-ig terjed. A beszédfrekvenciák tartományában (500-3000 Hz) átlagosan 30-55 dBHL erősítést biztosít.

\section{Az implantátum elhelyezése, rögzítése, technikai ajánlások}

A jelenleg forgalomban lévő beültethető egység (VORP 503 ) javasolt behelyezése a következő. Kiterjesztett retroauricularis feltárásból a mastoid planumtól posterior szabaddá kell tenni a csontfelszínt. Az implantátumtest (demodulátor és a mágneses tekercs) két önbehajtó menettel rendelkező csavarral rögzíthető a koponyacsonton. Mastoidectomiát végezve helyet készítünk a demodulátorból kilépő vezetéknek, majd az antrumot kellően feltágítva olyan posterior tympanotomiás nyílást hozunk létre, melyen keresztül kielégítő rálátást nyerünk az incudostapedialis ízületre, az incus hosszú nyújtványára vagy a kerek ablakra attól függően, hogy hol szeretnénk elhelyezni a rezgő egységet (6. ábra).

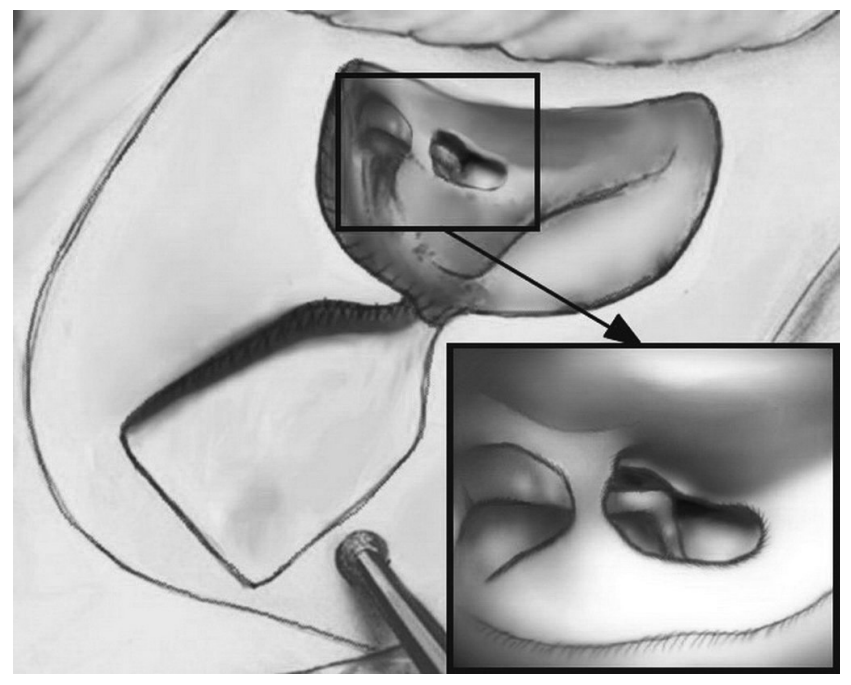

6. ábra A Vibrant Soundbridge rendszer implantátumának befogadásá hoz, rögzítéséhez kidolgozott mútéti terület 


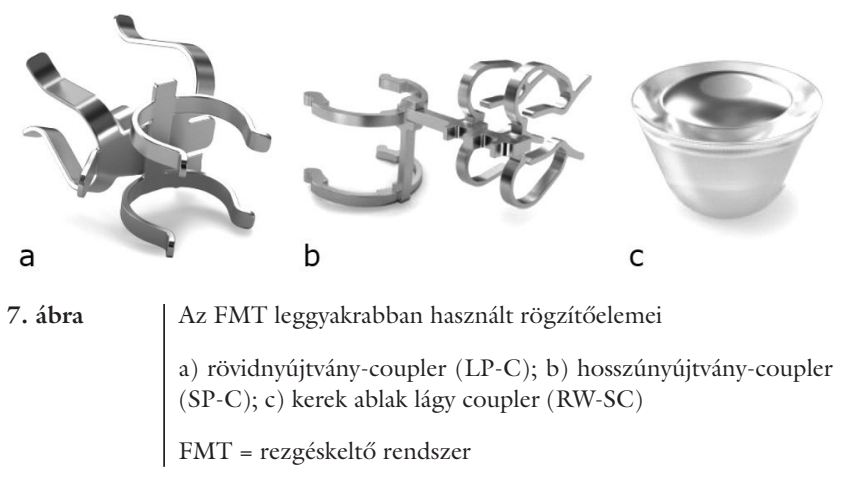

Az FMT-t speciális illesztőelemekkel (coupler) az incus hosszú, illetve rövid nyújtványára is rögzíthetjük, vagy az ún. „soft coupler” segítségével a kerek ablak membránjához is illeszthetjük (7. ábra). Lehetőség nyílik további megoldásokra is attól függően, hogy a középfül melyik képlete alkalmas a rezgés felvételére, továbbítására. A mútéti eljárás hatékonyságát segítendő, az FMT rögzítése után praktikus lépés intraoperatív electrocochleographiát végezni, mely a késóbbiekben hasznos lehet a beszédprocesszor beállítása szempontjából is.

Az operáció alsó korhatára a jelenlegi ajánlás szerint 5 év, habár Mandalà és munkacsoportja súlyos hallójárati és fülkagylófejlődési rendellenességtől szenvedő, néhány hónapos gyermekek esetén is jó eredményeket értek el VSB-implantációval [16]. Az FMT legújabb konstrukciójának köszönhetôen a készülék 1,5 T térerősségig MRI-kompatibilis.

\section{Indikáció és javasolt mütéti megoldások}

A klasszikus indikáció szerint a VSB-t sensorineuralis halláscsökkenés esetén javasolták olyan esetekben, amikor a légvezetéses hallásküszöb $500 \mathrm{~Hz}$-en nem haladta meg a $65 \mathrm{dBHL}-e s, 3-6 \mathrm{kHz}$-en pedig a $85 \mathrm{dBHL}$-es határt (8. ábra). A kezdetben ajánlott, ún. „vibroplastica” során (Ugo Fisch, az első operatốr ajánlása szerint) az FMT-t az incus hosszú nyújtványára kellett rögzíteni. Az így elérhető legnagyobb funkcionális nyereség $1-2 \mathrm{kHz}-$ en 28-37 dBHL-nek adódott [17].

Azokban az esetekben, amikor rekurráló otitis externával állunk szemben, vagy a hallókészülék elviselhetetlen akusztikus feedbackjelenséget, okklúziós effektust okoz, esetleg a fülkagyló és a hallójárat anatómiai rendellenessége (a hallójárat teljes atresiája/stenosisa) eleve megakadályozza a hallókészülékkel való rehabilitációt, észszerú megoldást nyújthat a VSB. Az ilyen esetekben továbbra is az FMT incuson való rögzítése javasolt. Ez történhet rövidnyújtvány-coupler (SP-C, short process coupler) vagy hosszúnyújtvány-coupler (LP-C, long process coupler) segítségével $(9 / a$ és $9 / 6$ ábra). Fontos, hogy a vezetéses, illetve kevert típusú halláscsökkenések során akkor indikálható a beavatkozás, ha a beteg csontvezetéses hallásküszöbe $500 \mathrm{~Hz}$-en nem haladja meg a

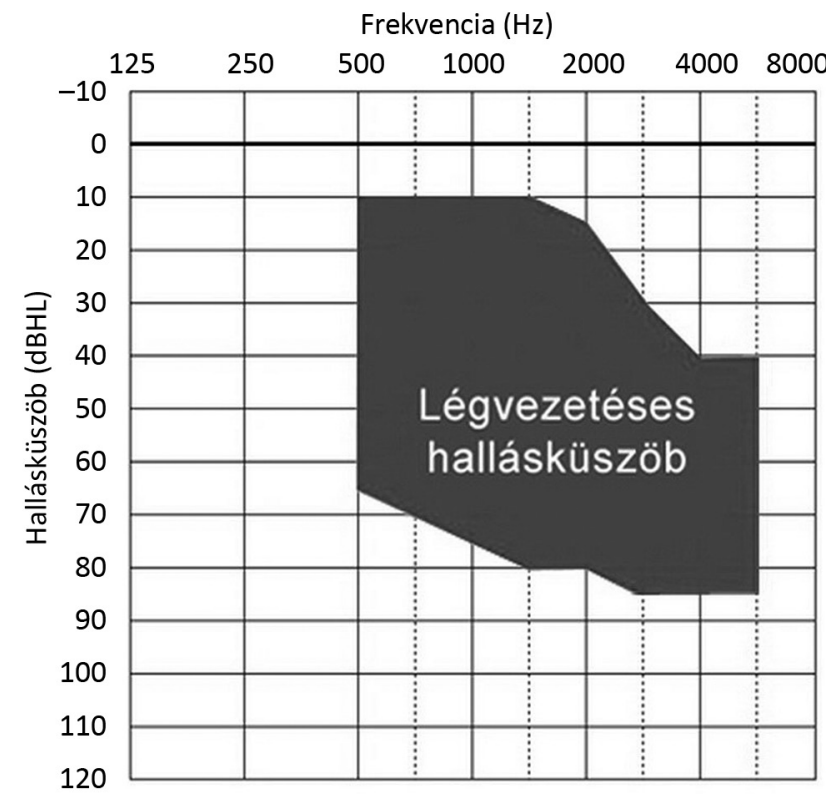

8. ábra $\mid$ A Vibrant Soundbridge audiológiai indikációja sensorineuralis halláscsökkenés esetén

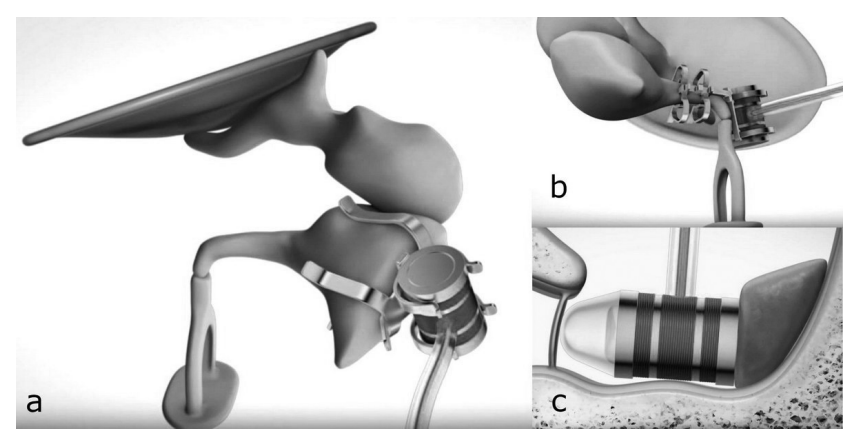

9. ábra

\begin{abstract}
Az FMT illesztésének leggyakrabban alkalmazott opciói
a) az incus rövid nyújtványára; b) az incus hosszú nyújtványára; c) a kerek ablak membránjához

FMT = rezgéskeltő rendszer
\end{abstract}

45 dBHL-t, továbbá 2-4 kHZ-en sem lehet rosszabb 65 dBHL-nél (10. ábra).

Amennyiben egy korábbi tympanoplastica, illetve hallócsontláncolat-pótlás után nem kielégítő a beteg hallásjavulása, vagy akár subtotalis petrosectomia - a középfül üregrendszerének megszüntetése - esetén (ha jó a beteg csontvezetéses hallása) ugyancsak elvégezhető a VSBimplantáció, de itt az FMT kerek ablakos alkalmazása preferálandó, melyhez a gyártó az „RW-SC (round window soft coupler)" nevú illesztőelemet fejlesztette ki (9/c ábra). Elsóként Coletti alkalmazta a kerek ablakos megoldást, de ő még lágy coupler hiányában a kerek ablak csontos peremének elfúrásával ért el jó kontaktust az FMT és a membrán között. Annak érdekében, hogy megakadályozzuk az FMT hypotympanumba való diszlokációját, egy porctámasztékkal ki is ékelhetjük, valamint a jó kontaktus érdekében az FMT és a membrán 


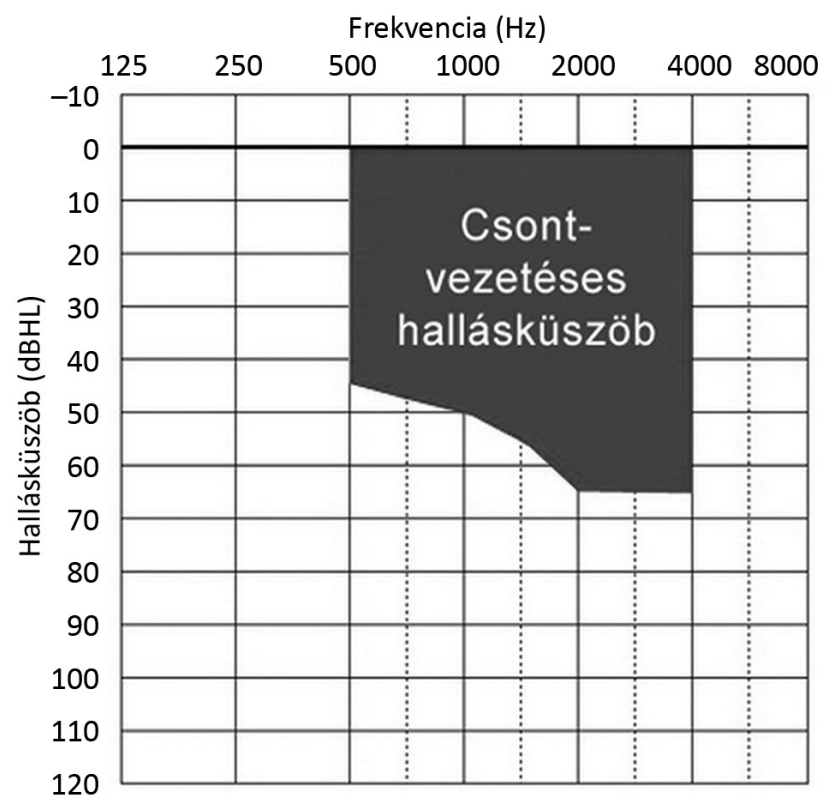

10. ábra A Vibrant Soundbridge audiológiai indikációja vezetéses, illetve kevert típusú halláscsökkenés esetén

közé fasciát vagy Tutoplastot (marhaszívburok-kivonat) tehetünk [18, 19]. A kerek ablakos megoldás azért is preferálandó, mert alkalmazásával függetlenítjük a transzmisszió hatásfokát a ligamentum baseos stapedistől, mely Hüttenbrink mérései szerint 90\%-ban eleve meghatározza a középfül átviteli impedanciáját [20]. Ezzel az alkalmazási móddal az elérhető funkcionális nyereség 28-55 dBHL [21].

További lehetőségek is léteznek, ezek közül azonban csupán még egyet emelnénk ki, mely stapesfixációval járó, közepes vagy súlyos fokú, kevert típusú halláscsökkenés esetén hozhat megoldást. Ezeknek az eseteknek mintegy kétharmada előrehaladott otosclerosisban jelentkezik. Az itt felmerülő lehetőség a stapedotomia és a VSB-implantáció szimultán kombinált alkalmazása, az ún. „power stapes” technika. A beültetendő eszközök rögzítésének sorrendje itt kifejezetten fontos. Még fixált hallócsontláncolat mellett kell az FMT-t felhelyezni az incusra, majd a stapes-superstructura eltávolítása és a stapedotomiás nyílás elkészítése után illeszthető és rög-

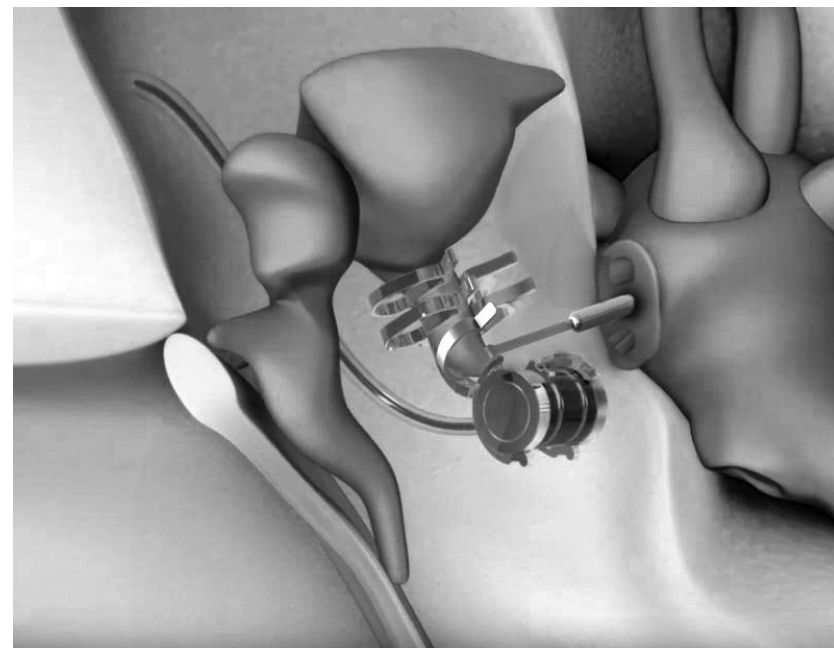

11. ábra

A Vibrant Soundbridge implantáció stapedotomiával kiegészített mútéti változatának lényege

zíthető a piston az incus hosszú nyújtványára (11. ábra). Ebben az esetben a piston a csont-lég-köz zárására hivatott, a VSB pedig további akusztikai erősítést visz a rendszerbe, így jó esetben a mútét előtti csontvezetéses hallásküszöbnél is jobb halláseredmény érhető el [22].

\section{Nemzetközi és saját tapasztalatok}

Kließ2018-as közleményében [23] 60 publikációt elemző, szisztematikus kvantitatív analízis segítségével számol be a jelenleg is elérhető aktív középfül-implantátumokkal kapott eredményekról a biztonság, a hatékonyság (funkcionális erősítés, beszédértés-javulás) és a betegek személyes megelégedettsége tekintetében, és konklúzióként a VSB-implantációt emeli ki mint a leghatékonyabb, továbbá legmegbízhatóbb, széles körben alkalmazható rehabilitációs lehetőséget.

Az utóbbi évek során arra is fény derült, hogy a VSB kedvezően játszik szerepet a tinnitustól szenvedő betegek hallásrehabilitációjában is. Csökkenti a fülzúgás intenzitását és jelentkezésének gyakoriságát is [24, 25]. Jelenleg a VSB egyensúlyproblémáktól szenvedő, senso-

1. táblázat |A pécsi implantációs programban a VSB-vel napjainkig elért audiológiai eredmények. Az „Átlagos funkcionális erôsítés értékei” oszlop betegcsoportonként szemlélteti a tisztahangküszöb $\left(\mathrm{PTA}_{4}\right)$ átlagos javulását (preop-posztop különbség), hasonlóképpen az utolsó két oszlopban is a preop-posztop változások átlagát tüntettük fel.

\begin{tabular}{lccc}
\hline $\begin{array}{l}\text { Mútéti megoldás } \\
\text { (az FMT rögzítésének helye) }\end{array}$ & Esetszám $(\mathrm{db})$ & $\begin{array}{c}\text { Átlagos funkcionális } \\
\text { erősítés }(\mathrm{dBHL})\end{array}$ & $\begin{array}{c}\text { Átlagos beszédhallásküszöb-javulás } \\
\text { SRT }_{50 \%}(\mathrm{dBHL})\end{array}$ \\
\hline Incus-LP & 11 & 23,125 & $\begin{array}{c}\text { Átlagos beszédértés-javulás } \\
\text { WRS }_{65 \mathrm{~dB}}(\%)\end{array}$ \\
\hline Incus-LP + piston („power stapes”) & 4 & 26,5625 & 33,75 \\
\hline Incus-SP & 5 & 18,8 & 13,5 \\
\hline Incus-SP + piston („power stapes”) & 2 & 23,75 & 16,25 \\
\hline RW & 2 & 27 & 21,25 \\
\hline
\end{tabular}

$\mathrm{dBHL}=$ decibel hallásszint; FMT = rezgéskeltő rendszer; LP = hosszú nyújtvány; RW = kerek ablak; SP = rövid nyújtvány; SRT = beszédhallás küszöb; VSB = Vibrant Soundbridge; WRS = százalékos beszédértés 
rineuralis halláscsökkenéssel rendelkező betegek körében való alkalmazhatóságáról is folynak tanulmányok [26].

A PTE KK Fül-Orr-Gégészeti és Fej-Nyaksebészeti Klinikáján eddig 15 olyan VSB-implantáció történt, melynél az FMT az incus hosszú nyújtványára került, 7 esetben a rövid nyújtványra, valamint 2 betegnél alkalmaztuk a kerek ablak membránjához való illesztést. Az 1. táblázat az FMT rögzítési helye alapján összegzi a kapott audiológiai eredményeinket. Külön csoportban jelenítettük meg az átlagos funkcionális erôsítés és beszédértés-nyereség értékeit azon eseteknél, ahol a VSB-implantáció stapedotomiával egészült ki. A funkcionális erősítés átlagát az 500, 1000, 2000 és 3000 Hzen mért tisztahang-hallásküszöbök preoperatív és posztoperatív értékei alapján számítottuk $\left(\mathrm{PTA}_{4}\right)$, a beszédhallásküszöb átlagos változását az 50\%-os számértéseredmények segítségével $\left(\mathrm{SRT}_{50 \%}\right)$, a százalékos beszédértés-javulás átlagát pedig $65 \mathrm{dBHL}$-es intenzitású, egy szótagú, fonetikailag kiegyensúlyozott szavak segítségével mértük $\left(\mathrm{WRS}_{65 \mathrm{dBHL}}\right)$. A teljes audiológiai vizsgálat során a hangingereket szabad hangtérben a beteg vizsgált fülétől egy méter távolságban elhelyezett hangszórók szolgáltatták. Amennyiben szükséges volt az ellenoldali fül maszkolása, ott hangingerként fejhallgatón adott fehérzajt alkalmaztunk.

Azt tapasztaltuk, hogy az LP-C-vel való rögzítés jobb halláseredményhez vezetett $(23,125 \mathrm{dBHL}$ átlagos funkcionális erősítés, 23,75 dBHL beszédhallásküszöbjavulás és $47 \%$ átlagos beszédértés-javulás), mint az SPC-vel rögzített FMT esetén (18,8 dBHL átlagos funkcionális erősítés, 13,5 dBHL beszédhallásküszöb-javulás és $45 \%$ átlagos beszédértés-javulás).

A tisztán VSB-vel rehabilitált csoportok közül abban az esetben tapasztaltuk a legjobb hallásjavulást, amikor az FMT a kerek ablak membránjával került kontaktusba (27 dBHL átlagos funkcionális erôsítés, 21,25 dBHL beszédhallásküszöb-javulás és $47,5 \%$ átlagos beszédértés-javulás). Amennyiben a VSB-implantáció stapedotomiával egészült ki, további erősítésnövekedés (5-10 dBHL) és beszédértés-javulás (15-30\%) volt megfigyelhető.

Eredményeink jellegüket tekintve összhangban állnak a nemzetközi szakirodalomban leírt tapasztalatokkal [17, 21-23], habár megjegyzendő, hogy a funkcionális nyereség számítása során figyelembe vett frekvenciák tekintetében nagy a diverzitás az egyes munkacsoportok között. Klinikánk betegei szubjektíve is pozitívan értékelték a rehabilitációval elért hallásélményüket, valamint a külső egység használatának egyszerüségét illetően is elégedettek voltak.

\section{Megbeszélés}

A középfül-implantátumok fejlődése során megjelentek teljesen, illetve részben implantálható készülékek is, melyek indikációs körüket és hatásfokukat tekintve igen széles skálán mozogtak. Egyes típusoknál azonban (mint például a Carina) igen magas komplikációs és meghibásodási rátáról számoltak be a közlemények [23]. A másik, gyakran felmerülő probléma az MRI-kompatibilitás hiánya volt. Költséghatékonysági és biztonsági megfontolások eredményeképpen ezek a rendszerek rövid életűnek bizonyultak. A VSB azonban - akár sensorineuralis, akár vezetéses, akár kevert típusú halláscsökkenésról legyen szó - már több mint két évtizede stabilan jelen van a rehabilitációs lehetőségek eszköztárában. Rezgéskeltő rendszerének univerzalitása révén és a hozzá beszerezhető couplerek sokféleségének köszönhetôen mintegy áthidalhatók vele a hallócsontláncolat sérült, illetve hiányzó struktúrái és a hallójárat rendellenességei, így nem csoda, hogy napjainkra közkedvelt megoldássá vált.

Minthogy a mai modern hallókészülékek a funkcionális nyereség tekintetében kiváló megoldást biztosítanak, a klinikai gyakorlatban a leginkább akkor jelenik meg mégis a VSB alkalmazása, amikor hallókészülékkel a beteg nem rehabilitálható, akár rekurráló otitis externa okán, akár elviselhetetlen feedbackjelenség, okklúziós effektus, külsőfül-anatómiai rendellenességek, váladékozó mastoid üreg esetén, illetve ha elégtelen mértékű a hallásjavulás hallócsontláncolat-pótlás vagy tympanoplastica után, továbbá subtotalis petrosectomia esetén (amennyiben jó a beteg csontvezetéses hallása). A hagyományos hallókészülékekkel szembeni hátrányként említendő, hogy a beteg a fülmútét ismert rizikófaktorainak van kitéve (siketség, szédülés, arcidegbénulás, a chorda tympani sérülése), ezek a mellékhatások azonban tapasztalt sebészek kezében elhanyagolhatóan ritkán jelentkeznek.

Amennyiben a VSB rezgéskeltő rendszerét az incus rövid vagy hosszú nyújtványára rögzítjük, l-2 kHz-en maximum 28-37 dBHL erősítés érhető el a segítségével [17], megfelelő illesztéssel a kerek ablakba helyezve pedig 28-55 dBHL [21]. A PTE KK Fül-Orr-Gégészeti és Fej-Nyaksebészeti Klinikájának gyakorlatában a legjobb funkcionális erősítés 29-35 dBHL-nek adódott különböző incusvibroplasticák esetén, kerek ablakos megoldással pedig maximum $30 \mathrm{dBHL}$-es erősítést értünk el. "Power stapes” technikával további erôsítés vihető a rendszerbe, így a legnagyobb funkcionális erôsítés beteganyagunkban 40 dBHL-nek adódott. Meg kell jegyeznünk azonban azt is, hogy a funkcionális erősítés számítási módjainak a különböző nemzetközi közleményekben alkalmazott változatossága és a beteganyag heterogenitása megnehezíti az eredmények összehasonlítását, saját eredményeink analízisét pedig relatíve kis beteganyagon végezhettük, melynek komolyabb statisztikai elemzése (standard deviáció, szignifikanciaszámítás) nem szolgáltatna további lényegi információt.

A hallásnyereség fóleg a közepes és magas frekvenciákat érinti, így ezen a tartományon eredményez nagyobb komfortérzetet a beteg számára. Tekintve, hogy a VSB $1.5 \mathrm{~T}$ térerósségig MRI-kompatibilis, előszeretettel alkalmazzák olyan esetekben is, amikor a betegnek más okból kifolyólag, például korábbi fej-nyaki tumor eltávo- 
lítás után (az esetleges kiújulás miatt) rendszeresen MRIkontrollra kell járnia.

Hazánkban a VSB 2014-ben vált a NEAK által finanszírozott hallásrehabilitációs eszközzé, és azóta is az implantológiai eljárások palettájának egyik fontos színfoltját képezi.

Anyagi támogatás: A közlemény megírása anyagi támogatásban nem részesült.

Szerzői munkamegosztás: Az irodalomkutatásban és a kézirat megírásában valamennyi szerző részt vett, valamint átolvasta és jóváhagyta a cikk végleges változatát.

Érdekeltségek: A szerzőknek nincsenek érdekeltségeik.

\section{Irodalom}

[1] Chasin M. Bone anchored and middle ear implant hearing aids. Trends Amplif. 2002; 6: 33-38.

[2] Haynes DS, Young JA, Wanna GB, et al. Middle ear implantable hearing devices: an overview. Trends Amplif. 2009; 13: 206214 .

[3] Hough J, Vernon J, Dormer K, et al. Experiences with implantable hearing devices and a presentation of a new device. Ann Otol Rhinol Laryngol. 1986; 95: 60-65.

[4] Hunter JB, Carlson ML, Glasscock ME 3rd. The ototronix MAXUM middle ear implant for sevear high-frequency sensorineural hearing loss: preliminary results. Laryngoscope 2016; 126: 2124-2127.

[5] Pelosi S, Carlson ML, Glasscock ME 3rd. Implantable hearing devices: the Ototronix MAXUM system. Otolaryngol Clin North Am. 2014; 47: 953-965.

[6] Glasscock ME. Middle ear implant versus hybrid cochlear implant for high-frequency sensorineural hearing loss. Otolaryngol Head Neck Surg. 2014; 151(1_Suppl): P217-P218.

[7] Perkins R. Earlens tympanic contact transducer: a new method of sound transduction to the human ear. Otolaryngol Head Neck Surg. 1996; 114: 720-728.

[8] Zenner HP, Maassen MM, Plinkert PK, et al. First implantation of a totally implantable electronic hearing aid in patients with inner ear hearing loss. [Erste Implantationen eines vollständig implantierbaren elektronischen Hörsystems bei Patienten mit Innenohrschwerhörigkeit.] HNO 1998; 46: 844-852. [German]

[9] Maassen MM, Lehner R, Leysieffer H, et al. Total implantation of the active hearing implant TICA for middle ear disease: a temporal bone study. Ann Otol Rhinol Laryngol. 2001; 110: $912-$ 916.

[10] Klein K, Nardelli A, Stafinski T. A systematic review of the safety and effectiveness of fully implantable middle ear hearing devices: the Carina and Esteem systems. Otol Neurotol. 2012; 33: 916921.

[11] Pulcherio JO, Bittencourt AG, Burke PR, et al. Carina ${ }^{\circledR}$ and Esteem $^{\oplus}$ : a systematic review of fully implantable hearing devices. PLoS ONE 2014; 9: el10636.
[12] Bittencourt AG, Burke PR, de Souza Jardim I, et al. Implantable and semi-implantable hearing aids: a review of history, indications and surgery. Int Arch Otorhinolaryngol. 2014; 18: 303310 .

[13] Grossöhnmichen M, Salcher R, Kreipe HH, et al. The Codacs ${ }^{\mathrm{TM}}$ direct acoustic cochlear implant actuator: exploring alternative stimulation sites and their stimulation efficiency. PLOS ONE 2015; 10: e0119601.

[14] Luetje CM, Brackman D, Balkany TJ, et al. Phase III clinical trial results with the Vibrant Soundbridge implantable middle ear hearing device: a prospective controlled multicenter study. Otolaryngol Head Neck Surg. 2002; 126: 97-107.

[15] Carlson ML, Pelosi S, Haynes SD. Historical developement of active middle ear implants. Otolaryngol Clin North Am. 2014; 47: 893-914.

[16] Mandalà M, Colletti L, Colletti V. Treatment of the atretic ear with round window vibrant soundbridge implantation in infants and children: electrocochleography and audiologic outcomes. Otol Neurotol. 2011; 32: 1250-1255.

[17] Fraysse B, Lavieille JP, Schmerber S, et al. A multicenter study of the Vibrant Soundbridge middle ear implant: early clinical results and experience. Otol Neurotol. 2001; 22: 952-961.

[18] Linder T, Schlegel C, DeMin N, et al. Active middle ear implants in patients undergoing subtotal petrosectomy: new application for the Vibrant Soundbridge device and its implication for lateral cranium base surgery. Otol Neurotol. 2009; 30: 41-47.

[19] Beltrame AM, Martini A, Prosser S, et al. Coupling the Vibrant Soundbridge to cochlea round window: auditory results in patients with mixed hearing loss. Otol Neurotol. 2009; 30: 194201.

[20] Hüttenbrink KB. Middle ear mechanics and their interface with respect to implantable electronic otologic devices. Otolaryngol Clin North Am. 2001; 34: 315-335.

[21] Colletti V, Soli S, Carner M, et al. Treatment of mixed hearing losses via implantation of a vibratory transducer on the round window. Int J Audiol. 2006; 45: 600-608.

[22] Powell HR, Pai I, Ghulam H, et al. An alternative approach to mixed hearing loss in otosclerosis: stapes surgery combined with an active middle-ear implant. J Laryngol Otol. 2018; 132: 457460.

[23] Kließ MK, Ernst A, Wagner J, et al. The development of active middle ear implants: a historical perspective and clinical outcomes. Laryngoscope Investig Otolaryngol. 2018; 3: 394-404.

[24] Marino R, Vieira DT, Rajan GP. Tinnitus and quality of life after round window vibroplasty. Int Tinnitus J. 2012; 17: 134-139.

[25] Seo YJ, Kim HJ, Moon IS, et al. Changes in tinnitus after middle ear implant surgery: comparisons with the cochlear implant. Ear Hear. 2015; 36: 705-709.

[26] Ernst A, Todt I, Wagner J. Dehiscence syndromes: diagnosis and treatment. [Dehiszenzsyndrome: Diagnostik und Therapie.] HNO 2016; 64: 790-796. [German]

(Tóth Tamás,

Pécs, Munkácsy M. u. 2., 7621 e-mail: toth.tamas@pte.hu)

A cikk a Creative Commons Attribution 4.0 International License (https://creativecommons.org/licenses/by/4.0/) feltételei szerint publikált Open Access közlemény melynek szellemében a cikk bármilyen médiumban szabadon felhasználható, megosztható és újraközölhetö, feltéve, hogy az eredeti szerző és a közlés helye, illetve a CC License linkje és az esetlegesen végrehajtott módositások feltüntetésre kerülnek. (SID_1) 